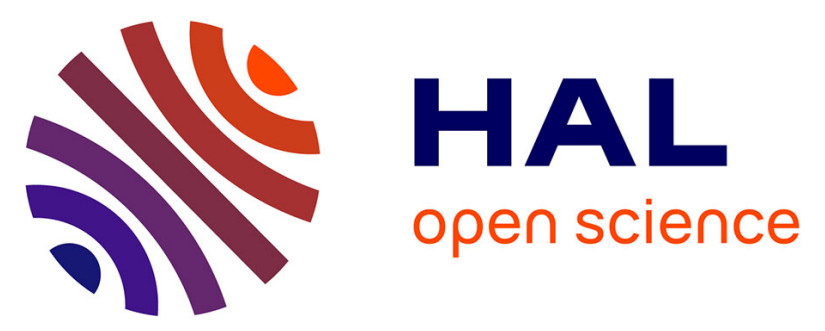

\title{
FEM CALCULATIONS AND EXPERIMENTAL DETERMINATION OF RESIDUAL STRESSES IN ALUMINA/NICKEL ALLOY JOINTS. OPTIMIZATION OF FABRICATION PARAMETERS
}

Lamine Hattali, Stéphane Valette, Francois Ropital, Nadir Mesrati, Daniel Tréheux

\section{To cite this version:}

Lamine Hattali, Stéphane Valette, Francois Ropital, Nadir Mesrati, Daniel Tréheux. FEM CALCULATIONS AND EXPERIMENTAL DETERMINATION OF RESIDUAL STRESSES IN ALUMINA/NICKEL ALLOY JOINTS. OPTIMIZATION OF FABRICATION PARAMETERS. Advanced Materials Research, 2010, 89-91, pp.238-243. 10.4028/www.scientific.net/AMR.89-91.238 . hal-00658250

\section{HAL Id: hal-00658250 https://hal.science/hal-00658250}

Submitted on 10 Jan 2012

HAL is a multi-disciplinary open access archive for the deposit and dissemination of scientific research documents, whether they are published or not. The documents may come from teaching and research institutions in France or abroad, or from public or private research centers.
L'archive ouverte pluridisciplinaire HAL, est destinée au dépôt et à la diffusion de documents scientifiques de niveau recherche, publiés ou non, émanant des établissements d'enseignement et de recherche français ou étrangers, des laboratoires publics ou privés. 


\title{
FEM CALCULATIONS AND EXPERIMENTAL DETERMINATION OF RESIDUAL STRESSES IN ALUMINA/NICKEL ALLOY JOINTS. OPTIMIZATION OF FABRICATION PARAMETERS
}

 \\ ${ }^{1}$ Laboratoire de Tribologie et Dynamique des Systèmes, UMR CNRS ECL ENISE ENSMSE \\ 5513, École Centrale de Lyon, 69134 Ecully cedex (France). \\ ${ }^{2}$ Laboratoire de Sciences et Génie des Matériaux, École Nationale Polytechnique d'Alger. \\ 10, avenue de Hassen Badi EL harrach Alger (Algérie). \\ ${ }^{3}$ IFP, BP 3-69360 Solaize (France). \\ ahattali.lamine@gmail.com, ${ }^{b}$ stéphane.valette@ec-lyon.fr, ${ }^{c}$ françois.ropital@ifp.fr, \\ dn_mesrati@yahoo.fr, edaniel.treheux@ec-lyon.fr
}

Keywords: solid state bonding; residual stress; X-ray diffraction; indentation; FEA simulation.

\begin{abstract}
The study relates to joints fabricated by solid state bonding between alumina and nickel alloy $\mathrm{HAYNES}^{\mathrm{TM}} 214^{\circledR}$, using an intermediate nickel metallic foil. Experimentally, damages and cracks often are observed close to the metal/ceramics interface. Consequently, the residual stresses distributions in the specimen were characterized experimentally using X-ray diffraction (XRD) and indentation techniques and predicted by Finite Element Analysis (FEA) calculations using an elasticplastic-creep model. We demonstrate that a good correlation between FEA calculations and experimental results is obtained. Then, the effect of elaboration and geometrical parameters has been studied in order to minimize the residual stresses in alumina close to the metal-ceramics interface. However, the $\mathrm{Al}_{2} \mathrm{O}_{3} / \mathrm{Ni} / \mathrm{HAYNES}^{\mathrm{TM}} 214^{\circledR}$ system always leads to high residual stresses. To solve this problem, we show that the use of a multi-layer $\mathrm{Cu} / \mathrm{Ni} / \mathrm{Cu}$ joint, associated with the Direct Copper Bonding method (DCB), by pre-oxidation of copper, allows reducing significantly the tensile residual stresses in ceramics.
\end{abstract}

\section{Introduction}

With ever greater demands being placed on materials, engineers and designers are turning their attention increasingly towards engineering ceramic e.g. silicon carbide, sialon and alumina to provide improvements in component performance and efficiency. However, in order to be exploited most effectively, ceramics must often be joined to metals [1-4]. These may be encountered mainly in composite materials designed for high-temperature applications and in structural metal-ceramic junctions. In general, ceramics and metals are joined at high temperature. The residual stresses of the joint will grow during the cooling process by the plastic constraint of both materials. This stress-field depends of many factors, e.g. the involved materials elastic and plastic properties, the levels and the temperature dependence of those properties, the thermal expansion coefficients, the unloadingrates and coolingrates used and the geometric design [5]. These stresses influence the strength and fracture toughness of the bond $[3,6]$. 
There is much work available on ceramics/metal joints who were interested to measure strains by diffraction techniques or neutron diffraction [7-8]. Other less precise methods were developed such as indentation method and layer removal techniques. It can present a good correlation with taken by measurements of X-ray diffraction [9]. On the other hand, a variety of analytical and numerical models has been too developed to understand and optimize the residual stress state in these materials [10-11]. But rarely were compared to experimentally measurement with result of classical XRD and indentation fracture method.

The aim of this research is to evaluate the residual-stress distribution of two types of bonded specimens, $\mathrm{Al}_{2} \mathrm{O}_{3} / \mathrm{Ni} / \mathrm{Al}_{2} \mathrm{O}_{3}$ and $\mathrm{Al}_{2} \mathrm{O}_{3} / \mathrm{Cu}-\mathrm{Ni}-\mathrm{Cu} / \mathrm{HAYNES}{ }^{\circledR} 214$, using the X-ray diffraction measurement and indentation fracture method. Experimental results being compared with predictions obtained using finite-element analysis of $\mathrm{Al}_{2} \mathrm{O}_{3} / \mathrm{Ni} / \mathrm{HAYNES}^{\circledR} 214^{\mathrm{TM}}$. The effect of elaboration and geometrical parameters has been studied in order to minimize the residual stresses in alumina close to the metal-ceramics interface. A novel and promising method proposed for creating high temperature resistant interfaces between dissimilar materials is the use a multi-layer $\mathrm{Cu} / \mathrm{Ni} / \mathrm{Cu}$ joint, associated with Direct Copper Bonding method (DCB), by preoxidation of copper. We demonstrated that, this technical joint reduces significantly the tensile residual stresses in ceramics.

\section{Experimental procedure}

Materials. With an aim of technology transfer, all the materials used in this work, are of industrial origin. The ceramic used in this work is alumina AL23 for Degussa $(>99.7 \%$ purity). The metal is nickel superalloy $\left(\right.$ HAYNES $^{\circledR} 214^{\mathrm{TM}}$ ), which is widely used in technological applications at high temperatures and in severe chemical atmosphere (petrochemical...). Both base material blocks were cut into small pieces with the dimension of $15 \mathrm{~mm} \times 5 \mathrm{~mm} \times 4 \mathrm{~mm}$ for bonding and for shear test at room temperature. The metal foils used were commercially available and were of high purity. The Ni foil used was $250 \mu \mathrm{m}$ thick with $99.5 \%$ purity and the $\mathrm{Cu}$ foil was $125 \mu \mathrm{m}$ thick with $99.8 \%$ purity. Prior to bonding, ceramics were polished using diamond pastes $(14 \mu \mathrm{m}-1 \mu \mathrm{m})$. The surfaces of metal interlayer and alloy were lightly polished with a silicon carbide abrasive paper in order to remove any oxidation layers. Just before bonding, all surfaces were cleaned by immersion in acetone with ultrasonic agitation for $0.5 \mathrm{~h}$. The base material blocks and the interlayer foil were prepared as block/foil/block sandwiched assembly, as shown in Fig. 1.

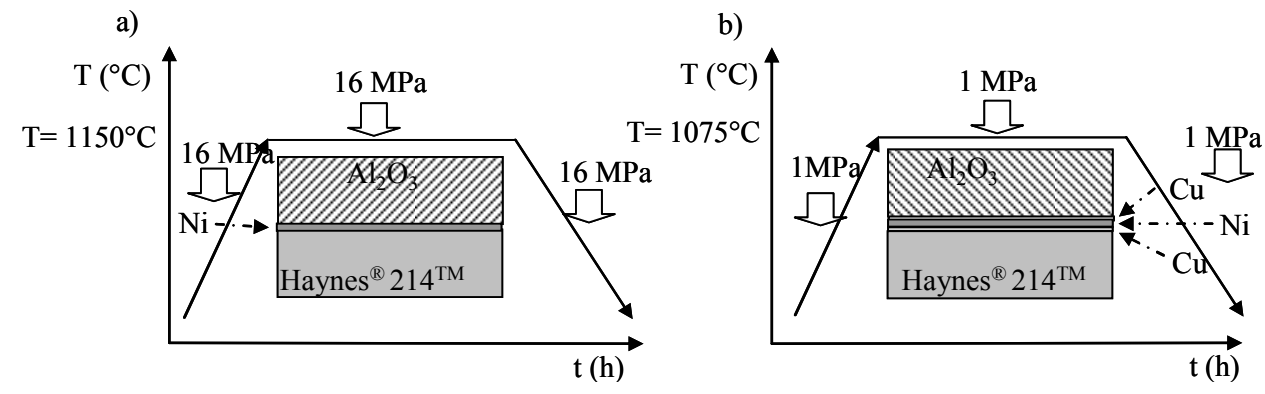

Figure 1: Sample fabricated for solid state bonding, and thermal cycle. a) Using Ni foil, b) using $\mathrm{Cu} / \mathrm{Ni} / \mathrm{Cu}$ interlayers.

Finally the ceramic-metal-alloy 'sandwiches' were bonded with a diffusion process by hot-pressing the assembly during $1 \mathrm{~h}$ at $1150{ }^{\circ} \mathrm{C}$. The pressure of $16 \mathrm{MPa}$ is applied through a pneumatic piston [2]. Heating speed was $150^{\circ} \mathrm{C} / \mathrm{h}$ and cooling speed was $200^{\circ} \mathrm{C} / \mathrm{h}$. The solid state bonding was carried out in primary dynamic vacuum $\left(10^{-3} \mathrm{~Pa}\right)$ during all the temperature cycle. The experimental conditions were selected taking into account previous studies $[2-3,12]$. 
FE analysis. Calculations were applied. Elasto-plastic-creep models for the metal and $\mathrm{Ni}$ based super-alloy were adopted. The joining of ceramics and metal is performed at high temperature at about $1150{ }^{\circ} \mathrm{C}$. Spatially uniform cooling (i.e., no thermal gradients) and perfect bonding at materials interface were assumed by quite small cooling rate. FE analysis is performed using ABAQUS program [13]. The conditions of calculations are thoroughly described in [6].

Indentation method. This method is based on the calculation of the difference between the lengths of cracks observed for the same ceramic before and after joining induced by indentations [9]. A Vickers indenter was impressed at several points on the ceramics surface at different distances from the interface. In the present investigation, the tests were conducted at a load of $300 \mathrm{~g}$ with a loading duration of $15 \mathrm{~s}$ every $50 \mu \mathrm{m}$, in diagonal, from the metal-ceramic interface to ceramic bulk. Liang and al. [14] have proposed an universal indentation equation allowing the direct calculation of $\mathrm{K}_{\mathrm{IC}}$ for both median and Plamqvist cracks. The formula is claimed to the use of any load to perform an indentation test.

$\mathrm{K}_{\mathrm{IC}}=\frac{\mathrm{H}_{\mathrm{V}} \mathrm{a}^{\frac{1}{2}}}{\alpha}\left(\frac{\mathrm{E} \varphi}{\mathrm{H}_{\mathrm{V}}}\right)^{0,4}\left(\frac{\mathrm{C}}{\mathrm{a}}\right)^{\frac{\mathrm{C}}{18 \mathrm{a}}-1,51}$

$\alpha=14\left[1-8\left(\frac{4 v-0.5}{1-v}\right)^{4}\right]$

Where $\mathrm{K}_{\mathrm{IC}}$ is the fracture toughness, $\mathrm{H}_{\mathrm{v}}$ is the hardness, $v$ the poisson's ratio, $\varphi$ is a constant close to 3 for alumina, $2 \mathrm{a}$ is the indent diagonal and $\mathrm{C}$ is the length of the radial crack. Lawn and Fuller [15] have suggested a relationship linking the modification of radial crack length to the level of stress $\sigma_{\mathrm{s}}$ in a surface layer of thickness $d$ taking into consideration the crack pattern produced by a standard point indenter. The residual stress in the ceramic can be calculated according to the following equation:

$\sigma_{\mathrm{r}}=\frac{K_{I C_{i}}}{(\pi C \Omega)^{\frac{1}{2}}}\left[1-\left(\frac{C_{i}}{C}\right)^{\frac{3}{2}}\right]$

Where $\mathrm{K}_{\mathrm{ICi}}$ is the substrate toughness, $\mathrm{C}_{\mathrm{i}}$ is the radial crack length before joint and $\Omega$ is a constant depending upon crack geometry $\left(\Omega=\frac{4}{\pi^{2}}\right)$.

Classical X-ray diffraction method. Residual stress measurement was carried out using a Dosophatex goniometer and INEL software equipments. The size of collimated X-ray beam $\left(\mathrm{CrK}_{\alpha 1}\right)$ for residual stress measurement was $\varnothing 800 \mu \mathrm{m}$. The stress diffraction technique, which was followed in the presented analysis, is thoroughly described in [16]. The $\mathrm{Al}_{2} \mathrm{O}_{3}$ (300) reflexion $\left(2 \theta=113^{\circ}\right)$ was used for strain determination. The $\mathrm{Al}_{2} \mathrm{O}_{3} / \mathrm{Ni} / \mathrm{HAYNES}^{\circledR}$ $214^{\mathrm{TM}}$ and $\mathrm{Al}_{2} \mathrm{O}_{3} / \mathrm{Cu} / \mathrm{Ni} / \mathrm{Cu} / \mathrm{HAYNES}^{\circledR} 214^{\mathrm{TM}}$ specimens were scanned along lines perpendicular to the joining plane to study the strain behaviour in regions near the joining interface (Fig.2, L1-line was at the free end of the specimen).

\section{Results and discussion}

$\mathrm{Al}_{2} \mathrm{O}_{3} / \mathrm{Ni} / \mathrm{HAYNES}^{\circledR} \mathbf{2 1 4}^{\mathrm{TM}}$; residual stress distribution. A contour map of the stress $\sigma_{\mathrm{yy}}$ perpendicular to the interface in an $\mathrm{Al}_{2} \mathrm{O}_{3} / \mathrm{Ni} / \mathrm{HAYNES}^{\circledR} 214^{\mathrm{TM}}$ joint calculated using the finite element method assuming Elasto-Plastic-Creep model is shown in Fig.2a. The distribution of residual stresses in ceramic-metal joint is not uniform even along the interface. 
According to this map, the maximum tensile stresses $\left(\sigma_{\mathrm{yy}}=234 \mathrm{MPa}\right)$ will be at the edge of the interface within the ceramic as suggested by the fracture appearance of the joints. Furthermore, finite element calculation shows that the maximum residual stress in the ceramic will increase with increasing thickness of the $\mathrm{Al}_{2} \mathrm{O}_{3}$ (Fig.2b), or more certainly on the ratio $\mathrm{R}^{\text {' }}$ between the thickness of the ceramics and the thickness of the alloy "Ec/Ea": Ec / $\mathrm{Ea}<1$ is recommended.
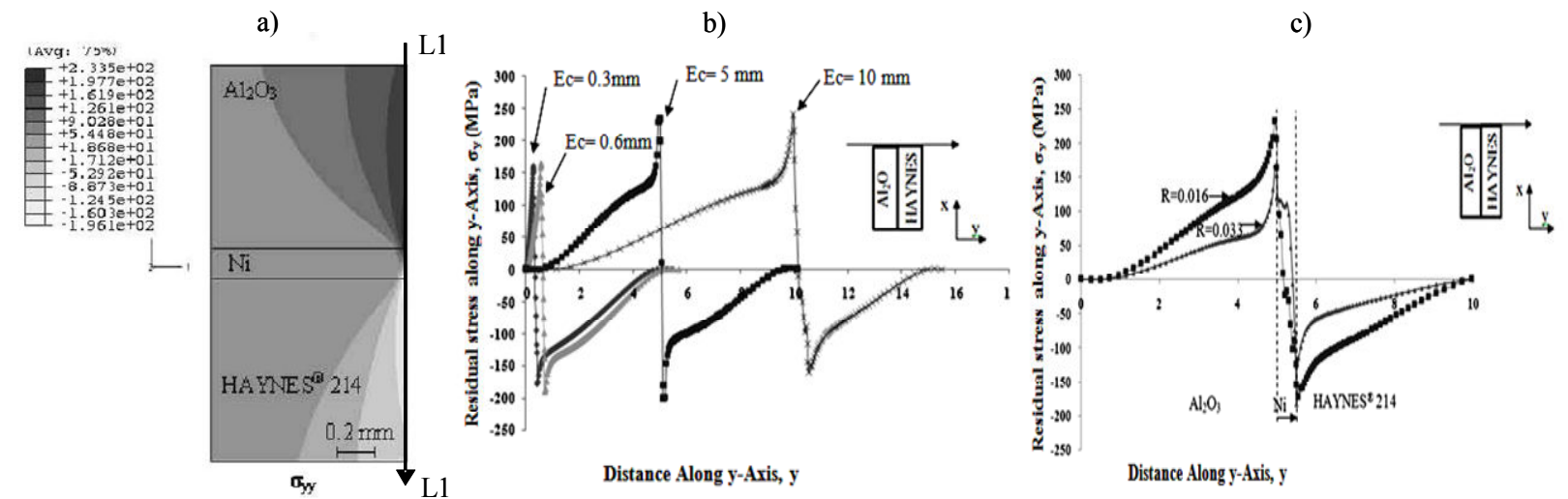

Figure.2: a) contour map of the perpendicular residual stress $\left(\sigma_{\mathrm{yy}}\right)$ in the $\mathrm{Al}_{2} \mathrm{O}_{3} / \mathrm{Ni} / \mathrm{HAYNES}{ }^{\circledR}$ $214^{\mathrm{TM}}$ joint. Predicted variation of tensile stress normal to interface $\mathrm{b}$ ) with varying thickness of alumina $(\mathrm{Ec}), \mathrm{c})$ with ration $\mathrm{R}$.

$\mathrm{R}^{\prime}=0.06$ in the case of $\mathrm{Al}_{2} \mathrm{O}_{3} / \mathrm{Ni} / \mathrm{HAYNES}^{\circledR} 214$ which explains the observed drastic reduction in shear stress test in preceding study [8]. But, an optimal thickness exists. In the same way, the geometry of the joint also plays a significant role on the intensity of the residual stresses, especially by the ratio $R=h / 1$ where 1 is the length of the contact and " $h$ " thickness of the seal. If $\mathrm{R}$ is low, high residual stresses are observed for $\mathrm{Al}_{2} \mathrm{O}_{3} / \mathrm{Ni} / \mathrm{HAYNES}{ }^{\circledR}$ 214 joints (Fig.2c). The optimum was obtained for $\mathrm{R}=0.033\left(\mathrm{Al}_{2} \mathrm{O}_{3} / \mathrm{Ni} / \mathrm{HAYNES}^{\circledR} 214\right)$. Figure 3 presents a comparison of the results for the residual stress distribution on the ceramic near to the interface as given by three different methods; FEA, indentation method and X-ray diffraction. Note that the magnitude of the peak stress measured experimentally by indentation fracture method is significantly higher than that predicted by X-ray diffraction and FE analysis.

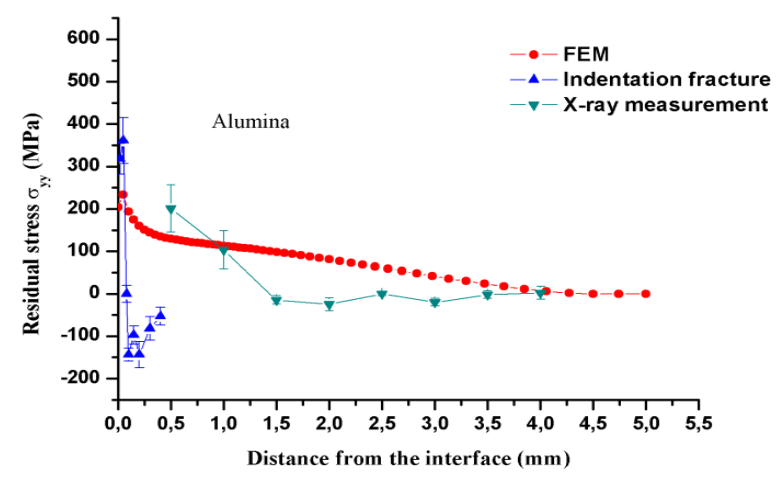

Figure 3: a) Comparison of the results for the residual stress distribution on the ceramic near to the interface as given by three different methods; FEA, indentation method and X-ray diffraction trough the L1 (Fig.2a).

All results show that the highest tensile stress appeared at the edge of the boundary. The residual stress may cause cracks in joint, or failure of bonding. The results of FE calculation and X-ray measurement did not agree very well but present a good correlation. One of the 
reasons of the disagreement might be that the X-ray measured stress is the average stress in the area of the X-ray beam spot. There are also some other considerable reasons of the disagreement of the results of FE analysis and X-ray stress measurement. For example, in FE analysis, the effect of the nickel diffusion in alumina on the residual stresses is not taken into account. The presence of shear stress at the ceramic side near the joint interface, in combination with the tensile stresses that are present, can induce fracturing along the ceramicmetal interface. Through fractographic analysis of the shear specimens, it is found that the crack initiates at the edge of the interlayer and then changes its direction into the ceramic and propagates into the ceramic part near the interface. This cracking type establishes that the ceramic parts near the interface have high tensile residual stress and are prone to cracking, as predicted by FEA.This phenomena is observed only in dissimilar $\mathrm{Al}_{2} \mathrm{O}_{3} / \mathrm{Ni} / \mathrm{HAYNES}^{\mathbb{R}} 214$ bonds [6]. Ceramics have poor fracture toughness, in particular close to the interface $\left(4 \mathrm{MPa} \mathrm{m}^{-1 / 2}\right)$, the cracks under the effect of high residual stress will downgrade the ceramic properties and may even lead to fracture. It is in accordance with the results of FEA analysis, $\mathrm{X}$-ray diffraction and indentation measurement.

$\mathrm{Al}_{2} \mathrm{O}_{3} / \mathrm{Cu} / \mathrm{Ni} / \mathrm{Cu} / \mathrm{HAYNES}^{\circledR} 214^{\mathrm{TM}}$; optimization of fabrication parameters. To compensate for thermal expansion mismatch effects, it is necessary to reduce the tensile part of the residual stress in a ceramic or at an interface. Ideas concerning the best configuration of such interlayers differ and include use of multi-component systems combining graded expansion and/or ductility e.g. $\mathrm{Cu}-\mathrm{Ni}, \mathrm{Cu}-\mathrm{Mo}$ [17]. The multi-layers using in this study is $\mathrm{Cu}-$ $\mathrm{Ni}-\mathrm{Cu}$, by pre-oxidation of copper in the $\mathrm{Al}_{2} \mathrm{O}_{3} / \mathrm{Cu}$ interface (DCB technique) [17]. The $\mathrm{Al}_{2} \mathrm{O}_{3} / \mathrm{Cu}-\mathrm{Ni}-\mathrm{Cu} / \mathrm{HAYNES}^{\circledR} 214^{\mathrm{TM}}$ joint were formed by diffusion bonding at $1075^{\circ} \mathrm{C}$ for 1 hour under pressure of $1 \mathrm{MPa}$ with $0.2 \mathrm{~mm}$ nickel and $0.125 \mathrm{~mm}$ copper interlayer. Between the temperature of $1065{ }^{\circ} \mathrm{C}$ and $1085{ }^{\circ} \mathrm{C}$, copper reacts with oxygen on the surface of the ceramic to form a eutectic liquid $\mathrm{Cu}-\mathrm{O}$, when cooled down, the $\mathrm{Cu}-\mathrm{Cu}_{2} \mathrm{O}$ eutectic solution consolidates to realize the good bonding. Interdiffusion causes the disappearance of the thin liquid film (eutectic), and post-solidification annealing at $1150{ }^{\circ} \mathrm{C}$ should lead to the formation of a uniform $\mathrm{Ni}$-rich $\mathrm{Cu}-\mathrm{Ni}$ solid solution in the interlayer region.

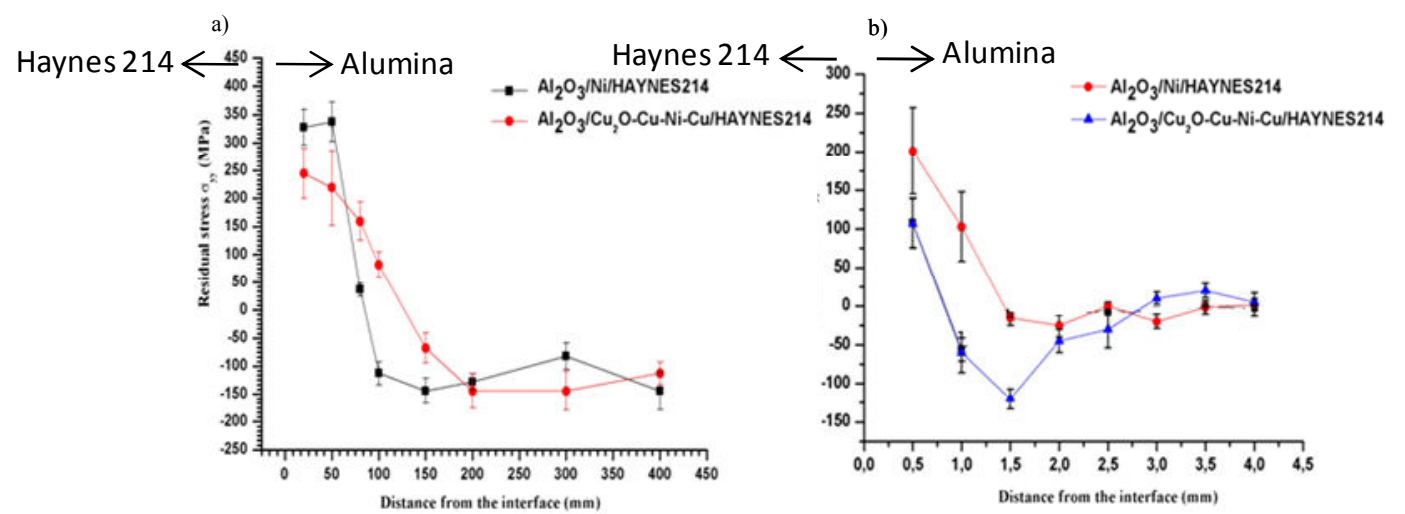

Figure 4: Experimetal determination of residual stress in both $\mathrm{Al}_{2} \mathrm{O}_{3} / \mathrm{Ni} / \mathrm{HAYNES}^{\circledR} 214^{\mathrm{TM}}$ and $\mathrm{Al}_{2} \mathrm{O}_{3} / \mathrm{Cu}-\mathrm{Ni}-\mathrm{Cu} / \mathrm{HAYNES}^{\circledR} 214^{\mathrm{TM}}$ joints, a) indentation method, b) X-ray diffraction method.

The characterizations by indentation technique and X-ray diffraction were performed to determine the residual stresses. The comparison of both $\mathrm{Al}_{2} \mathrm{O}_{3} / \mathrm{Ni} / \mathrm{HAYNES}^{\circledR} 214^{\mathrm{TM}}$ and $\mathrm{Al}_{2} \mathrm{O}_{3} / \mathrm{Cu} / \mathrm{Ni} / \mathrm{Cu} / \mathrm{HAYNES}^{\circledR} 214^{\mathrm{TM}}$ joint shows that the residual stresses concentration of the later joint is much lower than for the $\mathrm{Al}_{2} \mathrm{O}_{3} / \mathrm{Ni} / \mathrm{HAYNES}^{\circledR} 214^{\mathrm{TM}}$ one (Fig.4). Specimens bonded with $\mathrm{Cu} / \mathrm{Ni} / \mathrm{Cu}$ interlayers showed the potential for producing strong bonds- strengths 
as high as $\sim 70 \mathrm{MPa}$ (shear test) with cohesive ceramic failure. The Average shear strength of joints, bonded with Ni interlayer is about $30 \mathrm{MPa}$ [6].

\section{Conclusion}

In this paper, we have presented residual thermal stresses, developed during the fabrication of both $\mathrm{Al}_{2} \mathrm{O}_{3} / \mathrm{Ni} / \mathrm{HAYNES}^{\circledR} 214^{\mathrm{TM}}$ and $\mathrm{Al}_{2} \mathrm{O}_{3} / \mathrm{Cu}-\mathrm{Ni}-\mathrm{Cu} / \mathrm{HAYNES}^{\circledR} 214^{\mathrm{TM}}$ joints. Based on the results obtained in this work, the following conclusions can be drawn:

1- The importance of the geometry of the joint, characterized by the ratio $R=I / h$, where $I$ is the length of the contact area and " $h$ " the thickness of the $\mathrm{Ni}$ foil, is confirmed. For $\mathrm{Al}_{2} \mathrm{O}_{3} / \mathrm{Ni} / \mathrm{HAYNES}^{\oplus} 214$ joints, a low ratio can induce high residual stress concentrations leading to the brittleness. The optimum for this case is $R=0.033$.

2 - The role of the relative dimensions of alloy and ceramics $\left(R^{\prime}\right.$ ratio $=$ thickness of ceramics Ec / thickness Ea of metal). A high thickness of ceramics is harmful. The optimum is obtained for $\mathrm{R}^{\prime}=0.06$.

3- The residual stresses concentration of the $\mathrm{Al}_{2} \mathrm{O}_{3} / \mathrm{Ni} / \mathrm{HAYNES}^{\circledR} 214$ joint is much higher than for the $\mathrm{Al}_{2} \mathrm{O}_{3} / \mathrm{Cu}-\mathrm{Ni}-\mathrm{Cu} / \mathrm{HAYNES}^{\circledR} 214$ one. The Direct Copper Bonding method (DCB), by pre-oxidation of copper reduces significantly the tensile residual stresses in ceramics.

4- New approaches to joining ceramics for high-temperature applications using multilayer interlayers $\mathrm{Cu}-\mathrm{Ni}-\mathrm{Cu}$ have been explored, and the capability of forming strong $\mathrm{Al}_{2} \mathrm{O}_{3} / \mathrm{HAYNES}^{\circledR} 214^{\mathrm{TM}}$ joints has been demonstrated.

\section{References}

[1] A.G. Foley, D.J. Andrews: Tech. Rev. Vol. 13 (1994), p. 64.

[2] P. Lourdin, D. Juvé, D. Tréheux : J. Eur. Ceram. Soc. Vol. 16(7) (1996), p. 745.

[3] B. Serier, D. Tréheux: Acta. Metall. Mater. Vol. 41(2) (1993), p. 369.

[4] M.L. Hattali, S. Valette, F. Ropital, G. Stremsdoerfer, N. Mesrati, D. Tréheux: J. Eur. Ceram. Soc. Vol. 29 (2009), p. 813.

[5] C.A. Calow, I.T. Porter: J. Mater.Sci. Vol 6 (1971), p.156.

[6] M.L. Hattali, S. Valette, F. Ropital, N. Mesrati, D. Tréheux: J. Mater. Sci (to be published)

[7] Y. Nemoto, K. Ueda, M. Satou, A. Hasegawa, K. Abe: J. Nucl. Mater. Vol. 163 (1998), p. 1517.

[8] A.E. Martinelli, R.A.L. Drew, E.A Fancello, R. Rogge, J.H. Root: J. Am. Ceram. Soc. Vol. 82

(1999), p.1787

[9] G. Lascar: J. Phys IV. Vol. 4 (1998), p.115.

S.B Lee, J.H Kim: J. Mater. Process. Technol. Vol. 67(1997), p.167.

[10] D.N. Travessa, M. Ferrante, G. Den Ouden : J. Mater. Sci. Technol. Vol. 16 (2000), p.687.

[11] Tréheux D, Fayeulle S, Guipont V, Jacquemin JP. Interfacial science in ceramic joining, A bellosi et al. (eds.) 1998, 311-318.

[12] A. Kara-Slimane, B. Mbongo, D. Tréheux : J. Adhesion. Sci. Technol. Vol. 13(1999), p.3335.

[13] ABAQUS software, User's manual, version 6.6. Hibbitt, Karlsson and Sorensen Inc, (2006).

[14] K.M. Liang, G.Orange, G. Fantozzi : J. Mater. Sci. Vol. 25 (1990), p. 207.

[15] B.R. Lawn, J.R.Fuller: J. Mater. Sci. Vol. 19 (1984), p. 4061.

[16] W.D. Jenkins, T.G. Digges: J. Res. Nat Bureau of Standards. Vol. 48 (1952), p. 4.

[17] H. Hong, F. Renli, D. Wang, X. Song, M. Jing: J.Mater.Lett. Vol. 61 (2007), p. 4131 